\title{
PROCESSING OF TOFU INDUSTRIAL LIQUID WASTE WITH AERATION AND ADSORPTION COMBINED METHODS IN REDUCING LEVELS OF BOD, COD AND TSS IN TOFU INDUSTRY PELA MAMPANG,MAMPANG PRAPATAN SUB-DISTRICT - SOUTH JAKARTA 2018
}

\author{
Desembra Lisa, Syarifuddin, Rahayu Winarni \\ Jurusan Kesehatan Lingkungan, Politeknik Kesehatan Kemenkes Jakarta II, \\ Jl. Hang Jebat III/F3 Kebayoran Baru, Jakarta Selatan, 12120 \\ E-mail: desembralisa@gmail.com
}

\begin{abstract}
Liquid waste from tofu production is generated from the washing, boiling, pressing and molding process. Liquid waste disposal from tofu production have temperature of $37-45^{\circ} \mathrm{C}$, turbidity of $535-585 \mathrm{NTU}$, TSS, ammonia of 23.3-33.5 mg/L, BOD of 6000-8000 mg/l and COD of 7500-8400 mg/l. One of th techniques for the liquid waste processing from tofu production is aeration and adsorption. The purpose of this research is to know the combination of aeration and adsorption method in decreasing of BOD, COD and TSS in tofu wastewater at Pela Mampang tofu factory in Mampang subdistrict, South Jakarta in 2018. This research type is quasi experiment research, with research design of One Group Pre Test and Post Test Design. The sample of this research is tofu wastewater at Pela Mampang tofu factory in Mampang subdistrict, South Jakarta in 2018 with replication 5 times in each variation of contact time 20 minutes, 40 minutes, 60 minutes, 80 minutes and 100 minutes with observation parameters are BOD, COD and TSS. The results of the initial examination of BOD were $6244 \mathrm{mg} / \mathrm{l}$, COD $33800 \mathrm{mg} / \mathrm{l}$, and TSS $7100 \mathrm{mg} / \mathrm{l}$. After being treated with a combined method of aeration and adsorption the BOD levels decreased to $4300.4 \mathrm{mg} / \mathrm{l}$, COD $19283.6 \mathrm{mg} / \mathrm{l}$, and TSS $5246.6 \mathrm{mg} / \mathrm{l}$. There is a significant relationship between the time of treatment and reduction of BOD levels by 56.8\%, while COD and TSS have no significant relationship.
\end{abstract}

Keywords: Aeration, Adsorption, Liquid Waste Tofu

PENGOLAHAN LIMBAH CAIR INDUSTRI TAHU DENGAN METODE GABUNGAN AERASI DAN ADSORPSI DALAM MENURUNKAN KADAR BOD, COD DAN TSS DI INDUSTRI TAHU PELA MAMPAN KECAMATAN MAMPANG PRAPATAN-JAKARTA SELATANTAHUN 2018

\begin{abstract}
ABSTRAK
Limbah cair dari produksi tahu merupakan limbah yang dihasilkan dari proses pencucian, perebusan, pengepresan dan pencetakan tahu. Hasil buangan limbah cair dari proses produksi tahu memiliki suhu 37$45^{\circ} \mathrm{C}$, kekeruhan 535-585 NTU, TSS, amonia 23,3-33,5 mg/L, BOD 6000-8000 mg/L dan COD 7500$8400 \mathrm{mg} / \mathrm{L}$. Salah satu teknik pengolahan limbah cair tahu adalah aerasi dan adsorpsi. Penelitian ini bertujuan untuk mengetahui gabungan metode aerasi dan adsorpsi dalam menurunkan kadar BOD, COD dan TSS pada limbah cair tahu di pabrik tahu Pela Mampang Kecamatan Mampang Jakarta Selatan tahun 2018. Jenis penelitian ini adalah penelitian eksperimen semu dengan rancangan penelitian one group pre test dan post test design. Sampel penelitian ini yaitu limbah cair tahu di pabrik tahu Pela Mampang Kecamatan Mampang, Jakarta Selatan tahun 2018 dengan jumlah replikasi 5 kali pada masing-masing variasi waktu 20 menit, 40 menit, 60 menit, 80 menit dan 100 menit dengan parameter pemeriksaan yaitu BOD, COD dan TSS. Hasil pemeriksaan awal BOD 6244 mg/l, COD 33800 mg/l, dan TSS 7100 mg/l. Setelah diberikan perlakuan dengan metode gabungan aerasi dan adsorpsi terjadi penurunan kadar BOD menjadi 4300,4 mg/l, COD 19283,6 mg/l, dan TSS 5246,6 mg/l. Terdapat hubungan yang signifikan antara waktu perlakuan dengan penuruan kadar BOD sebesar 56.8\%, sedangkan COD dan TSS tidak terdapat hubungan yang signifikan.
\end{abstract}

Kata Kunci : Aerasi, Adsorpsi, Limbah Cair Tahu 
PENDAHULUAN

Tahu merupakan makanan tradisional masyarakat Indonesia yang dapat dikonsumsi oleh seluruh lapisan masyarakat. Selain mengandung gizi yang baik, pembuatan tahu juga relatif murah dan sederhana, serta harganya terjangkau oleh seluruh lapisan masyarakat. Lebih dari separuh konsumsi kedelai Indonesia dipergunakan untuk diolah menjadi tempe dan tahu. Data statistik dari Kementerian Perindustrian Republik Indonesia menunjukan kenaikan trend jumlah unit usaha kedelai sebesar $1,47 \%$ dan nilai produksi industri tahu kedelai sebesar $57,09 \%$ tiap tahunnya hingga tahun 2013 (1).

Dengan banyaknya industri tahu yang bertumbuh di Indonesia, tentu saja menimbulkan berbagai macam permasalahan. Salah satu masalah yang dihadapi dalam industri tahu adalah terkait dengan permasalahan limbah. Salah satu limbah utama dalam pengembangan industri tahu adalah limbah cair hasil produksi tahu yang bersifat polutif. Limbah cair dari produksi tahu dihasilkan dari proses pencucian, perebusan, pengepresan dan pencetakan tahu. Limbah cair hasil produksi tahu memiliki suhu berkisar $37-45^{\circ} \mathrm{C}$, kekeruhan 535-585 FTU, warna 2.225-2.250 Pt.Co, amonia 23,323,5 mg/l, BOD 5 6.000-8.000 mg/l dan COD 7.500-14.000 mg/l (2).

Jika ditinjau dari Kep/MENLH/5/2014 (3) tentang Baku Mutu Air Limbah bagi Usaha dan/atau Kegiatan Pengolahan Kedelai berupa Tahu, memiliki parameter maksimum BOD sebesar $150 \mathrm{mg} / \mathrm{l}$, COD sebesar $300 \mathrm{mg} / \mathrm{l}$ dan TSS sebesar $200 \mathrm{mg} / \mathrm{l}$. Menurut Peraturan Gubernur DKI Jakarta Nomor 69 Tahun 2013 (4) Tentang Baku Mutu Air Limbah Bagi Kesehatan dan/atau Usaha untuk industri makanan, kadar maksimum yang diperbolehkan untuk BOD sebesar $75 \mathrm{mg} / \mathrm{l}$, COD sebesar $100 \mathrm{mg} / \mathrm{l}$ dan TSS sebesar $100 \mathrm{mg} / \mathrm{l}$.

Limbah cair merupakan masalah utama dalam pengendalian lingkungan. Selain itu, limbah ini juga akan menimbulkan masalah bagi lingkungan jika tidak ditangani sebaik-baiknya. Pembuangan limbah ke lingkungan tanpa melalui proses penanganan yang baik akan mengancam kelestarian ekosistem yang berada disekitarnya. Adanya limbah ini tidak hanya berakibat buruk bagi lingkungan, tetapi juga aspek sosial karena dimungkinkan akan mengganggu masyarakat sekitar 
yang terkena limbah. Limbah yang dibuang di badan air tentu saja akan mencemari seluruh badan air sekitar. Sehingga mengganggu kehidupan mahluk hidup yang berada disekitar badan air tersebut.

Industri tahu di Jalan Bangka VII Pela Mampang, Kecamatan Mampang Prapatan-Jakarta Selatan, menghasilkan limbah cair tahu yang ditampung pada bak limbah lalu dibuang langsung ke badan air tanpa dilakukan pengolahan terlebih dahulu. Hal ini menyebabkan kekeruhan yang terlihat secara fisik di badan air dan juga timbulnya bau busuk dari limbah cair industri tahu yang dapat menggangu warga sekitar baik secara estetika maupun dari adanya kemungkinan timbulnya penyakit.

Oleh karena itu, diperlukan pengolahan limbah cair tahu sebelum dibuang ke badan air. Dalam proses pemilihan alternatif pengolahan limbah cair tahu, perlu dipertimbangkan baik dari segi kemampuan dalam menyisihkan polutan, serta kemampuan finansial. Salah satu alternatif pengolahan yang dapat digunakan adalah proses aerasi. Proses aerasi memiliki kelebihan yaitu biaya operasi dan perawatan yang murah serta memiliki efisiensi pengolahan zat organik yang tinggi. Selain itu, pengolahan limbah cair tahu juga dapat dilakukan dengan proses penyaringanosmosis, penyerapan karbon (absorbsi), pertukaran ion, saringan pasir serta penggumpalan dan pengendapan (5).Pengolahan limbah cair dengan proses adsorpsi memiliki kelebihan karena dapat mengurangi pengotoran bahan organik, partikel termasuk benda yang tidak dapat diuraikan (nonbiodegradable) ataupun gabungan antara bau, warna dan rasa.

Pada penelitian ini, peneliti akan menggunakan gabungan metode aerasi dan adsorpsi di dalam menurunkan kadar BOD, COD, dan TSS pada limbah cair pabrik tahu di industri tahu Jalan Bangka VII Pela Mampang, Kecamatan Mampang Prapatan-Jakarta Selatan. Dari hasil penelitian ini diharapkan gabungan metode aerasi dan adsorpsi dapat dipergunakan sebagai alternatif untuk mengatasi masalah pencemaran pada badan air dari limbah pabrik tahu.

\section{METODE PENELITIAN}

Dalam penelitian ini digunakan metode gabungan aerasi dan adsorpsi. Teknik aerasi adalah salah satu usaha pengolahan limbah cair dengan cara 
menambahkan oksigen ke dalam limbah cair tersebut. Penambahan oksigen adalah salah satu usaha dari pengambilan zat pencemar tersebut, sehingga konsentrasi zat pencemar akan berkurang atau bahkan dapat dihilangkan sama sekali. Sedangkan adsorpsi yaitu proses mengumpulkan benda-benda terlarut yang terdapat dalam dalam larutan dua permukaan. Antar permukaan itu bisa antara cairan dan gas, zat padat atau cairan, bahkan penyerapan dipergunakan pada permukaan zat padat dan zat yang kental.

Populasi dalam penelitian ini adalah limbah cair tahu yang mengandung kadar BOD, COD dan TSS di Jalan Bangka VII, Pela Mampang- Jakarta Selatan. Sampel dalam penelitian ini yaitu limbah cair tahu yang mengandung kadar BOD, COD dan TSS di Jalan Bangka VII, Pela Mampang-Jakarta Selatan. Limbah cair tahu ini secara fisik berwarna keruh, berbuih dan berbau masam.

Variable bebas dalam penelitian ini yaitu variasi waktu perlakuan dengan metode gabungan aerasi dan adsorpsi. Alat untuk menurunkan kadar BOD, COD, dan TSS pada limbah cair pabrik tahu berupa beaker glass yang dipasang aerator sebagai penyuplai oksigen yang dilakukan selama 100 menit, dengan variasi waktu 20 menit, 40 menit, 60 menit, 80 menit dan 100 menit, sedangkan teknik absorbsi menambahkan arang batok kelapa sebanyak 100 gram/L pada air limbah tahu pada masing-masing beaker glass. Sedangkan, variable terikat yaitu kadar BOD, COD, dan TSS sebelum perlakuan adalah kadar BOD, COD, dan TSS limbah cair industri tahu yang diturunkan menggunakan metode gabungan aerasi dan adsorpsi. Tahapan dalam penelitian ini dapat dijelaskan sebagai berikut.

\section{Persiapan Absorban}

Tahap awal diawali dengan pembuatan adsorban dari arang batok kelapa. Pada tahap ini, arang batok kelapa yang telah dibersihkan lalu dijemur dengan menggunakan panas matahari sampai kering dan kemudian disimpan dalam wadah yang tertutup.

\section{Pelaksanaan Uji Pendahuluan}

Tahap uji pendahuluan bertujuan untuk mengetahui kadar BOD, COD dan TSS pada keadaan sebelum perlakuan.

\section{Pelaksanaan Uji Penelitian}

Tahap uji penelitian bertujuan untuk mengetahui kadar BOD, COD dan TSS dengan variasi waktu proses aerasi 
secara berturut-turut 20 menit, 40 menit, 60 menit, 80 menit dan 100 menit. Proses awal dalam uji pendahuluan diawali dengan memasukan adsorban arang batok kelapa sebanyak 100 gr/l kedalam limbah cair tahu. Kemudian dilanjutkan dengan proses aerasi dengan variasi waktu dan replikasi sebanyak 5 kali untuk setiap variasi waktu. Setelah melakukan proses adsorpsi dan aerasi selanjut pemeriksaan kadar BOD, COD dan TSS.

Hasil penelitian dianalisis menggunakan teknik analisis univariat dan bivariat yang dapat dijelaskan sebagai berikut. Analisis Univariat dilakukan terhadap tiap-tiap variabel untuk mengetahui rata-rata (mean) hasil penelitian pada masing-masing perlakuan dan persentase perbedaan kadar BOD, COD dan TSS sebelum dan sesudah perlakuan.

Analisis Bivariat, Analisis data yang digunakan untuk mengetahui perbedaan penurunan kadar BOD, COD dan TSS pada limbah cair tahu di jalan Bangka VII Pela Mampang Jakarta Selatan sebelum dan sesudah diberikan perlakuan, penerapan gabungan teknik aerasi dan adsorpsi di lakukan dengan beberapa syarat. Skala pengukuran pada penlitian ini adalah skala numerik.

\section{HASIL DAN PEMBAHASAN}

Hasil pemeriksaan awal limbah cair tahu sebelum diberikan perlakuan diperoleh kadar BOD, COD dan TSS secara berturut-turut yaitu $6244 \mathrm{mg} / \mathrm{l}$, $33800 \mathrm{mg} / \mathrm{l}$, dan $7100 \mathrm{mg} / \mathrm{l}$. Hasil pemeriksaan awal sebelum diberikan perlakuam dapat dilihat pada Tabel 1

Berdasarkan Peraturan Gubernur DKI Jakarta No 69/2013 tentang Baku Mutu Limbah Cair Tahu, kadar limbah hasil pemeriksaan awal telah melebihi baku mutu.

Tabel 1 Hasil Pemeriksaan BOD, COD dan TSS Sebelum Perlakuan

\begin{tabular}{|c|c|c|}
\hline Parameter & Kadar Limbah & $\begin{array}{c}\text { Peraturan Gubernur DKI } \\
\text { Jakarta No 69/2013: Baku mutu }\end{array}$ \\
\hline BOD & $6244 \mathrm{mg} / \mathrm{l}$ & $75 \mathrm{mg} / \mathrm{l}$ \\
\hline COD & $33800 \mathrm{mg} / \mathrm{l}$ & $100 \mathrm{mg} / \mathrm{l}$ \\
\hline TSS & $7100 \mathrm{mg} / \mathrm{l}$ & $100 \mathrm{mg} / 1$ \\
\hline
\end{tabular}


Tabel 2 Persentase Hasil Penurunan Kadar BOD Berdasarkan Waktu Perlakuan dengan Metode Gabungan Aerasi dan Adsorpsi

\begin{tabular}{lccccc}
\hline \multirow{2}{*}{ Replikasi } & \multicolumn{5}{c}{ Waktu Perlakuan } \\
\cline { 2 - 6 } & 100 menit & 80 menit & 60 menit & 40 menit & 20 menit \\
\hline Replikasi 1 & 4582 & 4763 & 4280 & 5267 & 5005 \\
Replikasi 2 & 4421 & 4441 & 4924 & 5750 & 4945 \\
Replikasi 3 & 4240 & 4159 & 5206 & 5045 & 5629 \\
Replikasi 4 & 4039 & 4361 & 5025 & 4844 & 4978 \\
Replikasi 5 & 4220 & 4300 & 5086 & 5327 & 4945 \\
\hline Rata-rata & 4300,4 & 4404,8 & 4904,2 & 5246,6 & 5100,4 \\
Penurunan & 1943,6 & 1839,2 & 1339,8 & 997,4 & 1143,6 \\
\hline Penurunan (\%) & 31,13 & 29,46 & 21,46 & 15,97 & 18,32 \\
\hline
\end{tabular}

Hasil pemeriksaan uji sebenarnya untuk kadar BOD dengan menggunakan metode gabungan Aerasi dan Asorbsi dapat dilihat pada Tabel 2

Pada Tabel 2 dapat dilihat bahwa variasi waktu perlakuan mempengaruhi penurunan kadar BOD setelah perlakuan dengan metode gabungan aerasi dan absorbsi, dimana variasi waktu perlakuan 100 menit dapat menurunkan 31,13\% kadar BOD dalam limbah cair tahu dengan rata-rata penurunan kadar BOD sebesar 4300,4 $\mathrm{mg} / \mathrm{l}$.

Hasil pemeriksaan uji sebenarnya untuk kadar COD dengan menggunakan metode gabungan Aerasi dan Asorbsi dapat dilihat pada Tabel 3

Pada Tabel 3 dapat dilihat bahwa variasi waktu perlakuan mempengaruhi kadar COD setelah perlakuan dengan metode gabungan aerasi dan absorbsi,

Tabel 3 Persentase Hasil Penurunan Kadar COD Berdasarkan Waktu Perlakuan dengan Metode Gabungan Aerasi dan Adsorpsi

\begin{tabular}{lccccc}
\hline \multirow{2}{*}{ Replikasi } & \multicolumn{5}{c}{ Waktu Perlakuan } \\
\cline { 2 - 6 } & 100 menit & 80 menit & 60 menit & 40 menit & 20 menit \\
\hline Replikasi 1 & 23340 & 24628 & 23340 & 27042 & 31251 \\
Replikasi 2 & 19638 & 20121 & 18189 & 25433 & 30475 \\
Replikasi 3 & 22696 & 20443 & 16740 & 28813 & 32476 \\
Replikasi 4 & 23984 & 22470 & 17867 & 25272 & 33275 \\
Replikasi 5 & 26076 & 23018 & 20282 & 21087 & 8531 \\
\hline Rata-rata & 23146,8 & 22136 & 19283,6 & 25529,4 & 27201,6 \\
Penurunan & 10653,2 & 11664 & 14516,4 & 8270,6 & 6598,4 \\
\hline Penurunan $(\%)$ & 31,52 & 34,51 & 42,95 & 24,47 & 19,52 \\
\hline
\end{tabular}


dimana variasi waktu perlakuan 60 menit efektif menurunkan 42,95 \% kadar COD alam air limbah cair tahu dengan rata-rata penurunan kadar COD sebesar 19283,6 mg/l.

Hasil pemeriksaan uji sebenarnya untuk kadar TSS dengan menggunakan metode gabungan Aerasi dan Asorbsi dapat dilihat pada Tabel 4

Dari hasil Tabel 4 dapat dilihat bahwa variasi waktu perlakuan mempengaruhi kadar TSS setelah perlakuan dengan metode gabungan aerasi dan absorbsi, dimana variasi waktu perlakuan 20 menit efektif menurunkan 26,11 \% kadar TSS air limbah cair tahu dengan rata-rata penurunan kadar COD sebesar 5246,2 $\mathrm{mg} / \mathrm{l}$.

\section{SIMPULAN}

Hubungan waktu perlakuan dengan penurunan kadar BOD dan COD dalam limbah cair tahu menunjukan hubungan yang kuat berpola positif. Dimana, waktu efektif penurunan kadar BOD yaitu 4300,4 mg/l pada waktu perlakuan 100 menit. dan kadar COD yaitu 19283,6 mg/l dalam waktu perlakuan 60 menit. Sedangkan hubungan waktu perlakuan dengan penurunan kadar TSS menunjukan tidak ada hubungan.Sebelum pengolahan limbah cair tahu dengan metode gabungan aerasi dan adsorpsi sebaik nya limbah cair tahu diencerkan terlebih dahulu, untuk menghindari timbulnya buih pada limbah cair tahu.Selain itu penggunaan metode lain juga dapat digunakan seperti flokulasi untuk meningkat penurunan kadar parameter TSS.

\section{UCAPAN TERIMA KASIH}

Peneliti mengucapakan terima kasih kepada seluruh pihak yang membantu dalam penelitian ini. Terima kasih kepada Bapak Joko Sulistiyo, ST, M.Si selaku direktur Poltekkes Jakarta II dan Ibu Dr. Ir. Hj. Trina Astuti, MPS selaku kepala unit penelitian Poltekkes Jakarta II serta seluruh dosen dan staff Jurusan Kesehatan Lingkungan Poltekkes Jakarta II.

\section{DAFTAR PUSTAKA}

1. Kementerian Perindustrian RI; 2013 [cited2018 January 21] Perkembangan Jumlah Unit Usaha Industri Besardan Sedang Indonesia. Available from: http://kemenperin.go.id/ statistik/ibs_indikator.php?indikato $\mathrm{r}=1$

2. Herlambang.Teknologi Pengolahan Limbah Cair Industri Tahu. Jakarta: 
Pusat Pengkajian dan Penerapan

Teknologi Lingkungan dan Badan Pengendalian Dampak Lingkungan

Daerah Samarinda; 2002

3. Keputusan Menteri Lingkungan Hidup Nomor 5 Tahun 2014 Tentang Baku Mutu Air Limbah. Jakarta: Sekertariat Lingkungan Hidup.

4. Peraturan Gubernur No. 69 Tahun 2013. Tentang Baku Mutu Air Limbah Propinsi DKI Jakarta.

5. Sugiharto. Dasar-Dasar Pengolahan Air Limbah. Jakarta: Universitas Indonesia; 2005 